Review

\title{
The Putative Role of TP53 Alterations and p53 Expression in Borderline Ovarian Tumors - Correlation with Clinicopathological Features and Prognosis: A Mini-Review
}

\author{
Andrzej Semczuk ${ }^{1 凶}$, Marek Gogacz¹, Anna Semczuk-Sikora² ${ }^{2}$, Maciej Jóźwik ${ }^{3}$, Tomasz Rechberger ${ }^{1}$ \\ 1. IIND Department of Gynecology, Medical University of Lublin, Lublin, Poland; \\ 2. Department of Pathology of Pregnancy, Medical University of Lublin, Lublin, Poland: \\ 3. Department of Gynecology and Gynecologic Oncology, Medical University of Białystok, Białystok, Poland. \\ $\square$ Corresponding author: Andrzej Semczuk, MD, PhD, Professor of Obstetrics and Gynecology, IIND Department of Gynecology, Lublin Medical University, 8 \\ Jaczewski Str., 20-954 Lublin, Poland. Tel.: 004881 7244268; Fax: 0048817244 849; E-mail: andrzej.semczuk@umlub.pl \\ (c) Ivyspring International Publisher. This is an open access article distributed under the terms of the Creative Commons Attribution (CC BY-NC) license \\ (https://creativecommons.org/licenses/by-nc/4.0/). See http://ivyspring.com/terms for full terms and conditions.
}

Received: 2017.02.16; Accepted: 2017.06.07; Published: 2017.08.22

\begin{abstract}
Borderline ovarian tumors (BOTs) represent an independent group among ovarian malignancies, being diagnosed at clinical stage earlier than invasive ovarian carcinomas (OCs) and characterized by a rather favorable outcome after careful surgical management. Data published worldwide showed a substantial discordance of $\mathrm{p} 53$ expression in BOTs. The purpose of this work was to present the current status of knowledge on the significance of TP53 gene and $p 53$ protein product alterations in BOTs. In general, higher $\mathrm{p} 53$ expression patterns were reported for ovarian malignancies compared to BOTs. Serous, mucinous, and endometrioid BOTs differ substantially in relation to $\mathrm{p} 53$ immunostaining, but data concerning the relationship between the protein's immunoreactivity and other clinico-pathological variables are scarce. Finally, reports published to date support the view that TP53 alterations may not be commonly associated with the borderline phenotype of ovarian tumors but they probably occur during the development of invasive OCs. In light of these uncertainties, the impact of TP53 alterations and p53 expression on overall survival in women affected by BOTs requires further multi-institutional studies in large cohorts of patients.
\end{abstract}

Key words: p53, TP53, borderline ovarian tumor, prognosis.

\section{Introduction}

Borderline ovarian tumors (BOTs) were first described by Taylor in 1929 and they were then called "semimalignant tumors of the ovary" [1, 2]. Nowadays, they are also referred to as borderline tumors of the ovary, tumors of low malignant potential, or even atypical proliferative tumors of the ovary [3-5]. BOTs were officially classified by the International Federation of Gynecology and Obstetrics (FIGO) in 1961, and re-classified by a Committee of the World Health Organization (WHO) in 1973. The terminology and diagnostic criteria for BOTs, implemented by the new 2014 WHO
Classification of Tumors of the Female Genital Tract have been recently reviewed in detail by Hauptmann et al. [6]. One important change of this classification is the new terminology of non-invasive implants associated with serous BOT which, as any invasive foci (prior invasive implants), are now considered peritoneal low-grade serous carcinoma. Of note, even though only a small proportion of BOTs demonstrate features of microinvasion, these tumors have been classified according to consecutive FIGO classifications of ovarian carcinoma (OC), including the most current update [7]. 


\section{BOTs - incidence and clinico-pathologic features}

In general terms, BOTs are pathologically characterized by "hierarchical arborizing edematous papillae, focally covered by stratified epithelium with variable nuclear atypia with few mitoses and absence of destructive stromal invasion" [5]. As to histologic types, more than $96 \%$ of BOTs are either mucinous or serous subtypes, whereas other subtypes - for example, endometrioid, clear-cell, or Brenner transitional cell tumors - are uncommon $[4,8,9]$. At diagnosis, most of the cases are limited to one ovary only, representing FIGO stage I [9-11]. In relation with such an early clinical stage of the disease, the 5-year survival rate is approximately $97 \%[9,12]$. For more advanced stages of the disease (II-III), the 5-year survival rate approaches $87 \%$. Unfortunately, due to late recurrences, the 10-year survival rate may be less: $70-90 \%$. However, it should be beared in mind that a limited number of women will die early from the disease due to unfavorable prognostic factors, such as presence of invasive foci not resected completely at surgery [13-16]. Of importance, progression from BOT to invasive $\mathrm{OC}$ is approximately $2 \%$ and may be observed either in mucinous or serous subtypes [17]. By definition, rare cases of BOT with microinvasion, as an invasive disease, represent a higher risk for recurrence. Their monitoring with CA125 marker may have a role in the detection of recurrence [18]. Furthermore, young BOT patients with child-bearing potential are at a higher risk for recurrence, whereas older patients are at a higher risk for malignant transformation in peritoneal cavity or for distant metastases [19].

It is noteworthy that nearly $15-20 \%$ of all epithelial ovarian malignancies are finally diagnosed as BOTs. However, a number of characteristics differ BOTs from invasive epithelial OCs, for example FIGO stage at diagnosis, favorable overall outcome, or distribution of histological subtypes $[9,20]$. Although there has been a decreasing incidence of OC worldwide, several studies from Scandinavia showed an increased occurrence of BOTs within ovarian malignancies during the last decades [21, 22]. Women affected by BOT are nearly 10 years younger at diagnosis compared to patients with invasive OC [9, 23]. Moreover, the increased incidence of BOTs may be associated with the application of various stimulation protocols during in vitro fertilization techniques [24, 25].

In contrast, BOTs are uncommonly detected in patients with $B R C A$ mutations, as suggested by a nationwide study from Israel [26]. As concluded by Verbruggen et al. [27], "borderline ovarian tumors are neither part of the BRCA1- nor the BRCA2-related tumor spectrum".

In this context the data by Nayar et al. [28] is worth citing. These researchers reported that up to $10 \%$ of serous and mucinous BOTs demonstrate microinvasion, although the presence of this feature does not seem to significantly worsen prognosis in these patients. Similar observations were presented by others [29, 30]. Accordingly, Bell and Kurman [31] suggested that cytologic atypia and tumor microinvasion probably do not affect the prognosis of patients with endometrioid BOT. In a study by Roth et al. [32], 30 women with endometrioid BOT revealed a favorable prognosis compared to 32 patients with well-differentiated endometrioid ovarian adenocarcinoma.

In 2012, Morice et al. [33] looked at 80 advanced-stage serous BOT patients followed at the Gustave Roussy Institute, France for an over 30-year period (1969-1999). Invasive peritoneal foci was the only statistically established prognostic factor for evolution to invasive disease. However, another interesting finding in their analysis was that $8(10 \%)$ patients had nodal involvement with lymph node histological features similar to those of the primary serous BOT [33]. In line, a later German study confirmed that patients with invasive foci have higher relapse rates, yet their overall prognosis is not worsened [34].

\section{TP53 gene and p53 protein product}

TP53 has been labelled "the guardian of the genome" due to the fact that it prevents the proliferation of cells with damaged nuclear DNA [35-37]. This gene consists of 11 exons and is located on the short arm of chromosome 17 at region 17p13.1 $[35,38]$. Although most of TP53 genetic alterations have been found at exons 5-9, mutations outside this region have also been reported in various human malignancies [39-41]. It is noteworthy that TP53 is one of the most commonly mutated tumor suppressor genes in different human neoplasms, and it is involved in the development of at least a half of clinical tumors nowadays [38, 42, 43].

TP53 gene encodes p53 protein which comprises 393 amino acid residues [44]. The protein is composed of three main functional domains required for efficient binding to the recognition sites of the target genes. It is involved in a wide variety of important cellular functions, such as cell-cycle arrest at G1 and G2/M transitions, DNA repair, differentiation, senescence, and apoptosis (Fig. 1). p53 protein is present in normal cells at low levels and possesses a short half-life due to rapid turnover mediated by ubiquitination and proteolysis [45]. In cancer cells, 
alterations at TP53 result in the synthesis of a mutated protein with a prolonged half-life and increased stability and, consequently, the loss of the guardianship of the genome follows [46]. The loss of genomic stability allows for the progression of cells with damaged DNA through the cell cycle. Interestingly, not only p53 overexpression but also the absence of p53 immunostaining could be associated with TP53 alterations $[47,48]$. In cases when the TP53 becomes altered, the half-life of p53 protein becomes substantially longer and then it is possible to detect the protein applying different analytical methods, including Western blotting or immunohistochemistry $[36,49]$. In rare cases, however, when the TP53 mutations produce truncated proteins that are not overexpressed, even highly sensitive techniques may not detect the protein [50]. Interestingly, application of two immunohistochemical labelling patterns associated with TP53 mutations identified mutations in as many as $94 \%$ of OCs investigated [48].

\section{TP53 alterations in BOTs}

In primary human OCs, $30-80 \%$ of cases revealed TP53 alterations, functional point mutations, deletions and/or allelic loss [42, 48, 51-54]. As pointed out by Boyd and McCluggage [55], high-grade, but not low-grade, serous OCs are associated with point mutations at TP53 in a substantial proportion of cases. Of note, even early-stage sporadic OC patients harboring TP53 mutations were characterized by significantly worse progression-free and disease-specific survivals [56]. In BOTs, the incidence of TP53 alterations was found lower compared with that reported for human primary OCs, as estimated by several studies where it did not exceed $20 \%$ of cases [53, 54, 57, 58]. Yet, there are also data suggesting even the lack of TP53 alterations in BOTs [59]. Earlier, Kupryjańczyk et al. [57] reported that none of pure BOTs being analyzed harbored TP53 mutations, although gene mutations were reported in $40 \%$ of stage I OCs, including a borderline component adjacent to carcinoma in one case. In another study, only one case of BOT out of 9 had a point mutation, as evaluated with direct sequencing [53]. Not only micropapillary serous OCs but also serous borderline tumors lacked p53 mutations in the study by Katabuchi et al. [58]. Furthermore, Kmet et al. [45] reported a higher TP53 prevalence in mucinous BOTs compared to serous tumors of low malignant potential. Finally, genetic as well as immunohistochemical analysis of TP53/p53 alterations confirmed the hypothesis of the dual pathways of ovarian serous carcinogenesis and reported similar TP53 alterations in serous BOTs and low-grade serous OCs [54,59].

The data published to date supports the view that TP53 alterations (corresponding not in all cases to p53 overexpression, as discussed above) may not be commonly associated with the borderline phenotype of ovarian tumors, but rather occur during the development of invasive low-grade serous OCs [54, $57,59,60]$. Even though TP53 mutational status was correlated with p53 immunoreactivity in one study, the investigators studying the problem finally stated that "immunostaining is neither sufficiently specific nor sensitive enough to predict TP53 mutations" [54].

An important retrospective study by Ortiz et al. [61] is worth citing here. These authors reported that seven of eight $(88 \%)$ primary BOTs showed completely different TP53 mutations compared with gene alterations found in subsequent invasive serous OCs. Consequently, they suggested "a nonclonal origin for the serous BOTs compared with the subsequent grade I invasive serous epithelial ovarian carcinomas" [61].

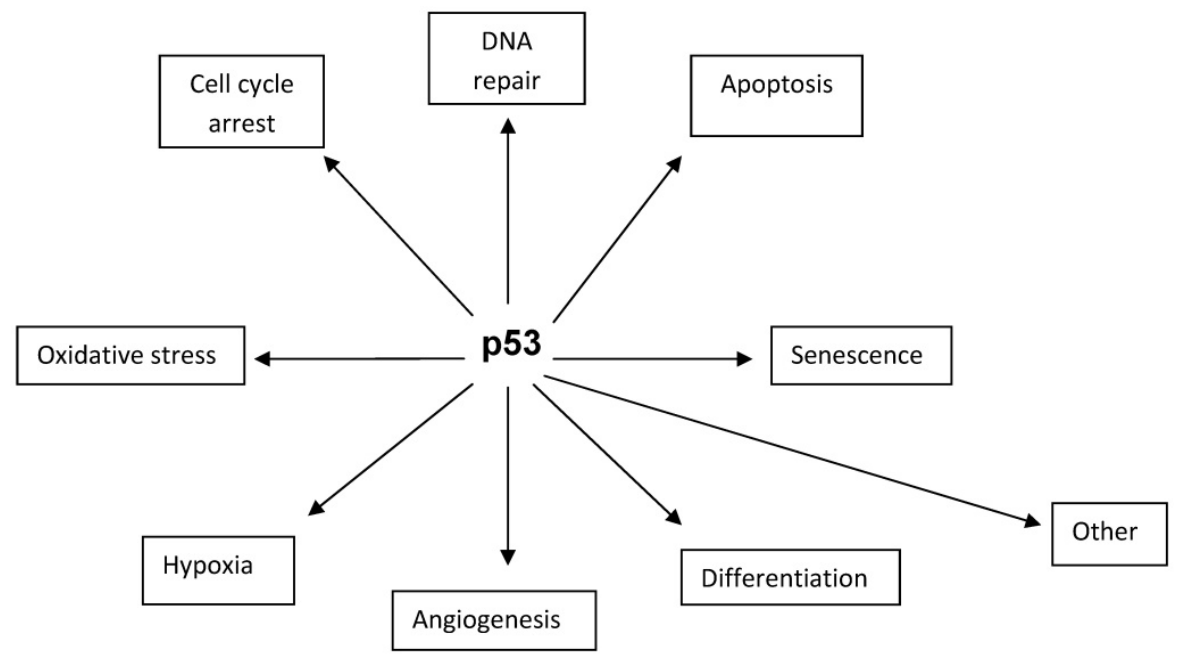

Figure 1. Some cellular functions of $\mathrm{p} 53$ protein. 
Table 1. An overview of reports on largest patient groups studied to date, presenting p53 expression patterns in primary human BOTs. Prognostic significance of p53 expression in tumors of low malignant potential was also included.

\begin{tabular}{|c|c|c|c|c|}
\hline Author(s) & No. of patients $(n)$ & p53-positive cases (n) & Percentage of p53-positive cases (\%) & Prognostic significance \\
\hline Nielsen et al. [50] & 85 & 17 & 20 & p53 is not a prognosticator \\
\hline Gershenson et al. [62] & 68 & 13 & 19 & $\begin{array}{l}\text { decreased } \text { OS }^{*} \text { and increased progression/ } \\
\text { recurrence in p53-positive cases }\end{array}$ \\
\hline Kuhn et al. [60] & 54 & 5 & 9 & no recurrence in p53 positive cases \\
\hline Berchuck et al. [63] & 49 & 2 & 4 & $\mathrm{NE}^{*}$ \\
\hline Kohlberger et al. [65] & 46 & 0 & 0 & $\mathrm{NE}$ \\
\hline Aktas et al. [80] & 44 & 30 & 68 & $\mathrm{NE}$ \\
\hline Ciepliński et al. [79] & 42 & 25 & 60 & $\mathrm{NE}$ \\
\hline Fauvet et al. [92] & 34 & 9 & 26 & $\mathrm{NE}$ \\
\hline Halperin et al. [89] & 20 & 0 & 0 & $\mathrm{NE}$ \\
\hline Lee et al. (1995) & 17 & 3 & 18 & $\mathrm{NE}$ \\
\hline Ozer et al. [91] & 16 & not reported & not reported & $\mathrm{NE}$ \\
\hline Gajewska et al. [74] & 16 & 15 & 94 & $\mathrm{NE}$ \\
\hline Giurgea et al. [73] & 15 & 1 & 7 & $\mathrm{NE}$ \\
\hline Miliaras [67] & 13 & 0 & 0 & $\mathrm{NE}$ \\
\hline Kupryjańczyk et al. [57] & 12 & 8 & 66 & no recurrence in p53 positive cases \\
\hline
\end{tabular}

*OS, overall survival; NE, not evaluated.

\section{p53 expression in BOTs}

For BOTs, data regarding the expression pattern of p53 are still a matter of controversy since this expression pattern has been reported with a considerable inter-observer variability. Table 1 overviews the largest studies investigating p53 expression pattern in human BOTs based on the data published. Significant differences reported in the literature concerning the striking variability in p53 staining in human BOTs (from 0 to $94 \%$ ) may be partly explained by different antibodies applied and various immunostaining techniques and methods of signal quantification used. A previous literature survey of clinical studies investigating p53 overexpression by stage in BOTs was conducted by Gershenson et al. in 1999 [62]. Examples of p53 immunostaining in primary human BOTs from our laboratory are shown in Figures 2A and 2B.

Some data reported a complete lack of p53 expression in ovarian tumors of low-malignant potential or a low $(<5 \%)$ immunoreactivity $[45,63-72]$. For example, none of 10 BOTs revealed p53 expression pattern by Gursan et al. [69]. In another report, only $6.6 \%$ of BOTs were p53-positive in contrast to benign ovarian tumors where positive reaction was not identified [73]. Interestingly, all 5 mucinous borderline tumors and $4(57 \%)$ out of 7 serous borderline tumors expressed p53 in a recent paper from India [72]. In a work from Poland, as many as $90 \%$ of OCs and $94 \%$ of BOTs showed positive p53 immunoreactivity, and the staining pattern differed significantly between malignant tumors and BOTs [74]. This paper presented the highest incidence of p53 expression in BOTs reported so far.
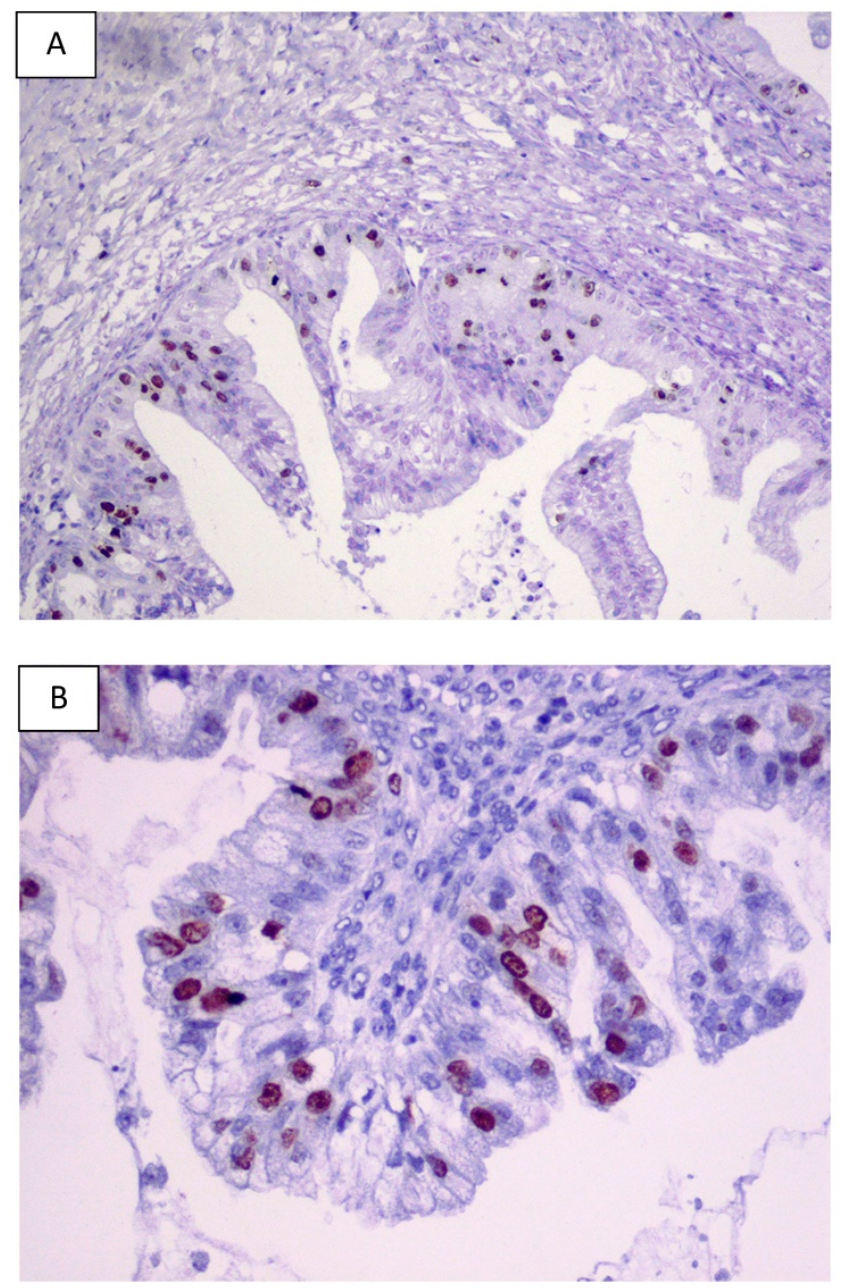

Figure 2. Examples of the $p 53$ immunostaining in primary human BOTs (A-B). Original magnifications: $100 \mathrm{x}$ and $200 \mathrm{x}$. 
Another study, Kuhn et al. [60], investigated a cohort of 54 BOTs divided into unilateral tumors $(\mathrm{N}=$ $38)$, bilateral tumors $(\mathrm{N}=8)$, and tumors with an additional component of invasive carcinoma $(\mathrm{N}=8)$. p53 protein was detected in one (3\%), $2(25 \%)$ and 2 $(25 \%)$ of the cases, respectively; thus, altogether $5(9 \%)$ of 54 tumors were positive. None of the 5 patients whose tumors revealed p53 reactivity displayed disease recurrence during follow-up. Previously, a similar outcome was published by Kupryjańczyk et al. following a 5-year follow-up of patients with tumors expressing p53 [75].

Marcelli et al. [76] reported a rate of $29 \%$ of serous BOTs displaying p53 expression, and somewhat similar percentage $(20 \%)$ was published by Sylvia et al. [71]. It has been suggested that p53 expression is significantly associated with tumor progression not only in serous [76], but also mucinous [75] BOTs. The p53 immunoexpression was observed in all BOTs at the nuclear level, yet only with mild intensity [77].

Our recent data showed that $60 \%$ of BOTs expressed p53 immunohistochemically [78, 79], similarly to results previously published by Aktas et al. [80]. No significant correlations between p53 expression and clinico-pathological variables of tumors were found. However, since information from 3 pregnant patients was included, we could verify and report for the first time that p53 expression in BOTs does not differ significantly between pregnant and non-pregnant subjects [79].

In the studies reviewed here, immunohistochemical analysis has been widely applied for the detection of p53 expression. Discrepancies in the percentage of reported p53-positive cases might have arisen from a potential loss of antigenic immunoreactivity during fixation process, and later in slides stored for prolonged period of time [81-83]. Some loss of histochemical reactivity between frozen and formalin-fixed slides has been underlined by reputed reviews previously [83-85]. However, both new methods of detection and monoclonal antibodies used reduce the loss of protein reactivity, even when using archival material [81, 82, $86,87]$.

Interestingly, immunoreactivity of p53 protein was significantly higher in BOTs, either serous or mucinous subtypes, than in adenocarcinomas of the ovary, although the study groups were not particularly large ( $\mathrm{N}=10$ for each arm) [88]. The main difference between BOTs and advanced serous papillary OCs was in regards to the increased overexpression of p53 and Ki-67 in the latter [89]. In contrast, the p53 expression was dramatically less in benign $(6 \%)$ than borderline $(75 \%)$ and malignant tumors $(81 \%)$, the differences being highly significant [73]. Similar observations were also published by others $[90,91]$. In another report, a highly significant difference in semi-quantitative p53 expression was detected between benign and borderline tumors, but not between borderline and malignant ovarian tumors [92]. Halperin et al. [89], the p53 immunostaining for benign ovarian serous cystadenomas did not differ significantly from that observed for BOTs, albeit the difference in staining between BOTs and advanced serous papillary OCs was of statistical significance.

Interestingly, a higher expression of p53 was associated with BOTs of serous type in a recent study by Tiwari et al. [93]. Similarly, p53 immunoreactivity was much more prevalent among malignant (36 of 81, or $44 \%$ ) than borderline ( 3 of 39 , or $8 \%$ ) tumors and it was particularly prevalent in serous OCs (16 of 26 , or $62 \%)$ [94]. On the other hand, no difference in p53 immunoreactivity between serous and mucinous BOTs was found by Fauvet et al. [92] and Gursan et al. [69], although others [91, 95] reported a significantly higher p53 expression rate in serous than mucinous tumors. Therefore, Giordano et al. [95] suggested that “... a significantly higher p53 expression rate observed in serous papillary cystadenocarcinomas than in mucinous cystadenocarcinomas and a higher p53 expression rate observed between borderline and malignant serous neoplasms can confirm a new model of ovarian carcinogenesis as suggested by Shih and Kurman" [96-97]. Collectively, a marked difference in p53 expression between histological subtypes of BOTs and invasive OCs has been commonly observed.

\section{Role of p53 immunostaining as a prognosticator for BOTs}

Data concerning the role of TP53 alterations and p53 overexpression as a prognosticator in patients affected by BOTs are limited to several reports $[50,57$, 60, 62] (Tab. 1). For example, none of 5 women with BOTs showing p53 immunoreactivity experienced a disease recurrence during a long follow-up [60]. Similar results were published by Kupryjańczyk et al. [57] where none of 8 patients affected by BOTs positive for p53 immunoreactivity, including tumors with microinvasion, revealed any evidence of recurrence during a 5-year follow-up. However, both studies included limited numbers of women and, therefore, it is not possible to draw final conclusions from them.

An interesting data was published by Gersherson et al. [62], showing that p53 overexpression was associated with an increased probability of advanced-stage serous BOT progression and recurrence, but also of decreased 
overall survival during follow-up. Women aged 30-49 years were almost four times more likely to have progressive/recurrent disease than younger women. Finally, in the age group of $\geq 50$ years, the presence of residual disease and p53 overexpression were found to be independent adverse risk factors for death. In contrast, neither univariate nor multivariate analysis revealed a significant prognostic effect in 85 BOTs patients during a long-term follow-up in a study by Nielsen et al. [50].

All in all, based on the literature review, except for Gersherson et al. [62], there are no studies suggesting an increased risk of recurrence and death from advanced-stage serous BOTs in patients whose tumors overexpressed p53. Relatively limited numbers of patients, lack of detailed information regarding treatment protocols and patient outcomes, as well as short durations of follow-up in some studies may have obscured the possibilities for drawing final conclusions yet.

\section{Closing remarks}

Data published worldwide demonstrates a substantial discordance of p53 expression in human BOTs. In general, patterns of higher p53 expression were reported for ovarian malignancies compared to BOTs. Serous, mucinous, and endometrioid BOTs differ markedly in regards to p53 immunostaining, however, data concerning the relationship between the protein's immunoreactivity and other clinico-pathological variables are scarce. Finally, reports published to date support the view that TP53 alterations may not be commonly associated with the borderline phenotype of ovarian tumors, but they probably occur during the development of invasive OCs [98-100]. Considering these uncertainties, the impact of TP53 alterations and p53 expression on overall survival in women affected by BOTs requires further multi-institutional studies in large cohorts of patients.

\section{Abbreviations}

BOT, borderline ovarian tumor; FIGO, International Federation of Gynecology and Obstetrics; OC, ovarian carcinoma; WHO, World Health Organization.

\section{Acknowledgment}

This work was supported in part by the Medical University of Lublin, Lublin, Poland (Grant No. $326 / 17$ to AS).

\section{Competing Interests}

The authors have declared that no competing interest exists.

\section{References}

[1] Taylor HC Jr. Malignant and semimalignant tumors of the ovary. Surg Gynecol Obstet. 1929; 48: 204-230.

[2] Trimble CL, Trimble EL. Ovarian tumors of low malignant potential. Oncology (Williston Park). 2003; 17: 1563-7.

[3] Seidman JD, Ronnett BM, Kurman RJ. Pathology of borderline (low malignant potential) ovarian tumours. Best Pract Res Clin Obstet Gynecol. 2002; 16: 499-512.

[4] McCluggage WG. The pathology of and controversial aspects of ovarian borderline tumours. Curr Opin Oncol. 2010; 22: 462-72.

[5] Seong SJ, Kim DH, Kim MK, Song T. Controversies in borderline ovarian tumors. J Gynecol Oncol. 2015; 26: 343-9.

[6] Hauptmann S, Fredrich K, Redline R, Avril S. Ovarian borderline tumors in the 2014 WHO classification: evolving concepts and diagnostic criteria. Virchows Arch. 2017; 470: 125-42.

[7] Berek JS, Crum C, Friedlander M. FIGO Cancer Report 2015. Cancer of the ovary, fallopian tube, and peritoneum. Int J Gynaecol Obstet. 2015; 131 (Suppl. 2): 111-22.

[8] Sengupta PS, Shanks JH, Buckley CH, Ryder WD, Davies J, Reynolds K, Slade RJ, Kitchener HC, Jayson GC. Requirement for expert histopatological assessment of ovarian cancer and borderline tumors. Br J Cancer. 2000; 82: 760-2.

[9] Fisherova D, Zikan M, Dundr P, Cibula D. Diagnosis, treatment, and follow-up of borderline ovarian tumors. Oncologist. 2012; 17: 1515-33.

[10] Kaern J, Trope CG, Abeler VM. A retrospective study of 370 borderline tumors of the ovary treated at the Norwegian Radium Hospital from 1970 to 1982 . A review of clinicopathologic features and treatment modalities. Cancer. 1993; 71: 1810-20.

[11] Behtash N, Modares M, Abolhasani M, Ghaemmaghami F, Mousavi M, Yarandi F, Hanjani P. Borderline ovarian tumours: clinical analysis of 38 cases. J Obstet Gynaecol. 2004; 24: 157-60.

[12] Trope C, Davidson B, Paulsen T, Abeler VM, Kaern J. Diagnosis and treatment of borderline ovarian neoplasms "the state of the art". Eur J Gynaecol Oncol. 2009; 30: 471-82.

[13] Michael H, Roth LM. Invasive and noninvasive implants in ovarian serous tumors of low malignant potential. Cancer. 1986; 57: 1240-7.

[14] Hart W. Borderline epithelial tumors of the ovary. Mod Pathol. 2005; 18 (Suppl. 2): 33-50.

[15] Yokoyama Y, Moriya T, Takano T, Shoji T, Takahashi O, Nakahara K, Yamada H, Yaegashi N, Okamura K, Izutsu T, Sugiyama T, Tanaka T, Kurachi H, Sato A, Tase T, Mizunuma H. Clinical outcomes and risk factors for recurrence in borderline ovarian tumours. Br J Cancer. 2006; 94: 1586-91.

[16] Morice P, Camatte S, Rey A, Atallah D, Lhommé C, Pautier P, Pomel C, Coté J-F, Haie-Meder C, Duvillard P, Castaigne D. Prognostic factors for patients with advanced stage serous borderline tumours of the ovary. Ann Oncol. 2003; 14: 592-8.

[17] Zanetta G, Rota S, Chiari S, Bonazzi C, Bratina G, Mangioni C. Behavior of borderline tumors with particular interest to persistence, recurrence, and progression to invasive carcinoma: a prospective study. J Clin Oncol. 2001; 19: 2658-64.

[18] Buttin BM, Herzog TJ, Powell MA, Rader JS, Mutch DG. Epithelial ovarian tumors of low malignant potential: the role of microinvasion. Obstet Gynecol. 2002; 99: 11-7.

[19] Trillsch F, Manher S, Woelber L, Vettorazzi E, Reuss A, Ewald-Riegler N, de Gregorio N, Fotopoulou C, Schmalfeldt B, Burges A, Hilpert F, Fehm T, Meier W, Hillemanns P, Hanker L, Hasenburg A, Strauss HG, Hellriegel M, Wimberger P, Baumann K, Keyver-Paik MD, Canzler U, Wollschlaeger K, Forner D, Pfisterer J, Schroeder W, Muendstedt K, Richter B, Kommoss F, Hauptmann S, du Bois A. Age-dependent differences in borderline ovarian tumours (BOT) regarding clinical characteristics and outcome: results from a sub-analysis of the Arbeitsgemeinschaft Gynaekologische Onkologie (AGO) ROBOT study. Ann Oncol. 2014; 25: 1320-7.

[20] Prat J. Ovarian tumors of borderline malignancy (tumors of low malignant potential): a critical appraisal. Adv Anat Pathol.1999; 6: 247-74.

[21] Bjorge T, Engeland A, Hansen S, Trope CG. Trends in the incidence of ovarian cancer and borderline tumours in Norway, 1954-1993. Int J Cancer. 1997; 71: 780-6.

[22] Skimisdottir I, Garmo H, Wilander E, Holmberg L. Borderline ovarian tumors in Sweden 1960-2005: trends in incidence and age at diagnosis compared to ovarian cancer. Int J Cancer. 2008; 123: 1897-1901.

[23] Seidman JD, Kurman RJ. Ovarian serous borderline tumors: a critical review of the literature with emphasis on prognostic indicators. Hum Pathol. 2000; 31: 539-57.

[24] Morice P. Borderline tumours of the ovary and fertility. Eur J Cancer. 2006; 42: 149-58.

[25] van Leeuwen FE, Klip H, Mooij TM, van de Swaluw AM, Lambalk CB, Kortman M, Laven JS, Jansen CA, Helmerhorst FM, Cohlen BJ, Willemsen WN, Smeenk JM, Simons AH, van der Veen F, Evers JL, van Dop PA, Macklon NS, Burger CW. Risk of borderline and invasive ovarian tumours after ovarian stimulation for in vitro fertilization in a large Dutch cohort. Hum Reprod. 2011; 26: 3456-65.

[26] Gotlieb WH, Chetrit A, Menczer J, Hirsh-Yechezkel G, Lubin F, Friedman E, Modan B, Ben-Baruch G. National Israel Ovarian Cancer Study Group. Demographic and genetic characteristics of patients with borderline ovarian 
tumors as compared to early stage invasive ovarian cancer. Gynecol Oncol. 2005; 97: 780-3.

[27] Verbruggen MB, Zweemer RP, Piek JM, van Unnik GA, van Diest PJ, Gille JJ, Menko FH, Dorsman JC, Verheijen RH. A case of loss of heterozygosity in the BRCA2 gene of a borderline ovarian tumor: case report and review of literature. Int J Gynecol Cancer. 2007; 17: 1143-7.

[28] Nayar R, Siriaunkgul S, Robbins KM, McGowan L, Ginzan S, Silverberg SG. Microinvasion in low malignant potential tumors of the ovary. Hum Pathol. 1996; 27: 521-7.

[29] Bell DA, Scully RE. Ovarian serous borderline tumors with stromal microinvasion: A report of 21 cases. Hum Pathol. 1990; 21: 397-403.

[30] McKenney JK, Balzer BL, Longacre TA. Patterns of stromal invasion in ovarian serous tumors of low malignant potential (borderline tumors): a reevaluation of the concept of stromal microinvasion. Am J Surg Pathol. 2006; 30: 1209-21.

[31] Bell KA, Kurman RJ. A clinicopathologic analysis of atypical proliferative (borderline) tumors and well-differentiated endometrioid adenocarcinomas of the ovary. Am J Surg Pathol. 2000; 24: 1465-79.

[32] Roth LM, Emerson RE, Ulbright TM. Ovarian endometrioid tumors of low malignant potential: a clinicopathologic study of 30 cases with comparison to well-differentiated endometrioid adenocarcinoma. Am J Surg Pathol. 2003; 27: 1253-9.

[33] Morice P, Uzan C, Fauvet R, Gouy S, Duvillard P, Darai E. Borderline ovarian tumour: pathological diagnostic dilemma and risk factors for invasive or lethal recurrence. Lancet Oncol. 2012; 13: e103-15.

[34] Lenhard MS, Mitterer S, Kümper C, Stieber P, Mayr D, Ditsch N, Friese K, Burges A. Long-term follow-up after ovarian borderline tumor: relapse and survival in a large patient cohort. Eur J Obstet Gynecol Reprod Biol. 2009; 145: 189-94.

[35] Lane D. Anthony Dipple Carcinogenesis Award: p53 from pathway to therapy. Carcinogenesis. 2004; 25: 1077-81.

[36] Darnton SJ. p53. Mod Pathol. 1998; 51: 248-53.

[37] Farnebo M, Bykov VJ, Wiman KG. The p53 tumor suppressor: a master regulator of diverse cellular processes and therapeutic target in cancer. Biochem Biophys Res Commun. 2010; 396: 85-9.

[38] Levine AJ, Momand J, Finlay CA. The p53 tumor suppressor gene. Nature. 1991; 351: 453-6.

[39] Greenblatt MS, Bennett WP, Hollstein M, Harris CC. Mutations in the p53 tumor suppressor gene: clues to cancer etiology and molecular pathogenesis. Cancer Res. 1994; 54: 4855-78.

[40] Steele RJ, Thompson AM, Hall PA, Lane DP. The p53 tumour suppressor gene. Br J Surg. 1998; 85: 1460-7.

[41] Petitjean A, Achatz MI, Borresen-Dale AL, Hainaut P, Olivier M. TP53 mutations in human cancers: functional selection and impact on cancer prognosis and outcomes. Oncogene. 2007; 26: 2157-65.

[42] Leroy B, Anderson M, Soussi T. TP53 mutations in human cancer: database reassessment and prospects for the next decade. Hum Mutat. 2014; 35: 672-688.

[43] Meek DW. Regulation of the p53 response and its relationship to cancer. Biochem J. 2015; 469: 325-46.

[44] Vogelstein B, Kinzler KW. p53 function and dysfunction. Cell. 1992; 70: 523-6.

[45] Kmet LM, Cook LS, Magliocco AM. A review of p53 expression and mutation in human benign, low malignant potential, and invasive epithelial ovarian tumors. Cancer. 2003; 97: 389-404

[46] Ashcroft M, Vousden KH. Regulation of p53 stability. Oncogene. 1999; 18 : 7637-43.

[47] Mittal K, Soslow R, McCluggage WG. Application of immunohistochemistry to gynecologic pathology. Arch Pathol Lab Med. 2008; 132: 402-23.

[48] Yemelyanova A, Vang R, Ksirsagar M, Lu D, Marks MA, Shih IEM, Kurman RJ. Immunohistochemical staining patterns of p53 can serve as a surrogate marker for TP53 mutations in ovarian carcinoma: an immunohistochemical and nucleotide sequencing analysis. Mod Pathol. 2011; 24:1248-53.

[49] Geisler J, Geisler H, Wiemann M, Givens S, Zhou Z, Miller G. Quantification of p53 in epithelial ovarian cancer. Gynecol Oncol. 1997; 66: 435-8.

[50] Nielsen JS, Jakobsen E, Holund B, Bertelsen K, Jakobsen A. Prognostic significance of p53, Her-2, and EGFR overexpression in borderline and epithelial ovarian cancer. Int J Gynecol Cancer. 2004; 14: 1086-96.

[51] Kupryjańczyk J, Thor A, Beauchamp T, Merritt V, Edegerton SM, Bell DA, Yandell DW. p53 gene mutation and protein accumulation in human ovarian cancer. PNAS. 1993; 90: 4961-5.

[52] Wertheim I, Muto MG, Welch WWR, Bell DA, Berkowitz RS, Mok SC. p53 gene mutation in human borderline epithelial ovarian tumor. J Natl Cancer Inst. 1994; 86: 1549-51.

[53] Lee JH, Kang YS, Park SY, Kim BG, Lee ED, Lee KH, Park KB, Kavanagh JI, Wharton JT. p53 mutation in epithelial ovarian carcinoma and borderline ovarian tumor. Cancer Genet Cytogenet. 1995; 85: 43-50.

[54] Singer G, Stohr R, Cope L, Dehari R, Hartmann A, Cao D-F, Wang T-L, Kurman RJ, Shih I-M. Patterns of p53 mutations separate ovarian serous borderline tumors and low- and high-grade carcinomas and provide support for a new model of ovarian carcinogenesis: a mutational analysis with immunohistochemical correlation. Am J Surg Pathol. 2005; 29: 218-24.

[55] Boyd C, McCluggage WG. Low-grade ovarian serous neoplasms (low-grade serous carcinoma and serous borderline tumor) associated with high-grade serous carcinoma or undifferentiated carcinoma: report of a series of cases of an unusual phenomenon. Am J Surg Pathol. 2012; 36: 368-75.
[56] Leitao MM, Boyd J, Hummer A, Olvera N, Arroyo CD, Venkatraman E, Baergen RN, Dizon DS, Barakat RR, Soslow RA. Clinicopathologic analysis of early-stage sporadic ovarian carcinoma. Am J Surg Pathol. 2004; 28: 147-59.

[57] Kupryjańczyk J, Bell DA, Dimeo D, Beauchamp R, Thor AD, Yandell DW. p53 gene analysis of ovarian borderline tumors and stage I carcinomas. Hum Pathol. 1995; 26: 387-92.

[58] Katabuchi $\mathrm{H}$, Tashiro $\mathrm{H}$, Cho RR, Kurman RJ, Hendrick Ellenson L Micropapillary serous carcinoma of the ovary: an immunohistochemical and mutational status of p53. Int J Gynecol Pathol. 1998; 17: 54-60.

[59] Avril S, Hahn E, Specht K, Hauptmann S, Hoss C, Kiechle M, Hofler H, Schmalfeldt B. Histological features of ovarian borderline tumors are not predictive of clinical outcome. Gynecol Oncol. 2012; 127: 516-24.

[60] Kuhn W, Marx D, Meidel A, Fattahi-Meibodi A, Korabiowska M, Ruschenburg I, Droese M, Schauer A, Meden H. Borderline tumors of the ovary: a clinico-pathologic and immunohistochemical study of 54 cases. J Obstet Gynaecol Res. 1998; 24: 437-45.

[61] Ortiz BH, Ailawadi M, Colitti C, Muto MG, Deavers M, Silva EG, Berkowitz RS, Mok SC, Gershenson DM. Second primary or recurrence? Comparative patterns of p53 and K-ras mutations suggest that serous borderline ovarian tumors and subsequent serous carcinomas are unrelated tumors. Cancer Res. 2001; 64: 7264-67.

[62] Gershenson DM, Deavers M, Diaz S, Tortolero-Luna G, Miller BE, Bast RC Jr, Mills GB, Silva EG. Prognostic significance of p53 expression in advanced-stage ovarian serous borderline tumors. Clin Cancer Res. 1999; 5: 4053-8.

[63] Berchuck A, Kohler MF, Hopkins MP, Humphrey PA, Robboy SJ, Rodriguez GC, Soper JT, Clearce-Pearson DL, Bast RC. Overexpression of p53 is not a eature of benign and early-stage borderline epithelial ovarian tumours. Gynecol Oncol. 1994; 52: 232-6.

[64] Klemi PJ, Takahashi S, Joensuu H, Kiilholma P, Narimetsu E, Mori M. Immunohistochemical detection of p53 protein in borderline and malignant serous ovarian tumors. Int J Gynecol Pathol. 1994; 13: 228-33.

[65] Kohlberger PD, Kieback DG, Mian C, Wiener H, Kainz C, Gitsch G, Breitenecker G. Numerical chromosomal aberrations in borderline, benign, and malignant epithelial tumors of the ovary: correlation with p53 protein overexpression and Ki-67. J Soc Gynecol Investig. 1997; 4: 262-4.

[66] Darai E, Walker-Combrouze F, Mlika-Cabanne N, Feldmann G, Madelenat P, Scoazec JY. Expression of p53 protein in borderline epithelial ovarian tumors: a clinicopathologic study of 39 cases. Eur J Gynaecol Oncol. 1998; 19: 144-9.

[67] Miliaras D. Volume-corrected mitotic index and p53 immunoreactivity in borderline and malignant epithelial ovarian tumors. Anal Quant Cytol Histol. 1999; 21: 425-9.

[68] Chan WY, Cheung KK, Schorge JO, Huang LW, Welch WR, Bell DA, Berkowitz RS, Mok SC. Bcl-2 and p53 protein expression, apoptosis, and p53 mutation in human epithelial ovarian cancers. Am J Pathol. 2000; 156: 409-17.

[69] Gursan N, Sipal S, Calik M, Gundogdu C. P53, Bcl-2, Ki-67 li (labeling index) status in benign, proliferative, and malignant ovarian surface epithelial neoplasms. Eurasian J Med. 2009; 41: 10-4.

[70] Leonhardt K, Einenkel J, Sohr S, Engeland K, Horn LC. p53 signature and serous tubal in-situ carcinoma in cases of primary tubal and peritoneal carcinomas and serous borderline tumors of the ovary. Int J Gynecol Pathol. 2011; 30: 417-24.

[71] Sylvia MT, Kumar S. Dasari P. The expression of immunohistochemical markers estrogen receptor, progesterone receptor, Her-2-neu, p53, and Ki-67 in epithelial ovarian tumors and its correlation with clinicopathologic variables. Indian J Pathol Microbiol. 2012; 55: 33-7.

[72] Naik PS, Deshumukh S, Khandeparkat SGS, Joshi A, Babanagare S, Potdar J, Risbud NS. Epithelial ovarian tumors: Clinicopathological correlation and immunohistochemical study. J Midlife Health. 2015; 6: 178-83.

[73] Giurgea LN, Ungureanu C, Mihailovici MS. The immunohistochemical expression of p53 and $\mathrm{Ki} 67$ in ovarian epithelial borderline tumors. Correlation with clinicopathological factors. Rom J Morphol Embryol. 2012; 53: 967-73

[74] Gajewska M, Wielgoś M, Panek G, Marczewska J. [Incidence of proapoptotic proteins p53 and p21 in epithelial ovarian tumors] (In Polish). Ginekol Pol. 2014; 85: 111-6.

[75] Kupryjańczyk J, Bell DA, Yandell DW, Scully RE, Thor AD. p53 expression in ovarian borderline tumors and malignant serous ovarian tumors. Am J Clin Pathol. 1994; 102: 671-6.

[76] Marcelli AR, Demopoulos RI, Goswami S, Mittal KR. Comparison of p53 and MIB1 expression in benign and borderline areas of ovarian serous tumors. Int J Gynecol Pathol. 1996; 15: 39-44.

[77] Marinas MC, Mogos DG, Simionescu CE, Stepan A, Tanase F. The study of p53 and p16 immunoexpression in serous borderline and malignant ovarian tumors. Rom J Morphol Embryol. 2012; 53: 1021-5.

[78] Semczuk A, Mrozek A, Semczuk-Sikora A, Gałczynski K, Lewkowicz D, Nowakowski $\mathrm{,} \mathrm{Postawski} \mathrm{K.} \mathrm{TP53} \mathrm{alterations} \mathrm{and} \mathrm{p53} \mathrm{expression} \mathrm{in}$ borderline ovarian tumors (BOTs) in humans. Int J Mol Med. 2016; 38 (Suppl.1): S77.

[79] Ciepliński K, Jóźwik M, Semczuk-Sikora A, Gogacz M, Lewkowicz D, Ignatov A, Semczuk A. Expression of p53 and selected proliferative markers (Ki-67, MCM3, PCNA, and topoisomerase IIa) in borderline ovarian tumors: correlation with clinicopathological features. Histol Histopathol. 2017; 32: in press. 
[80] Aktas IY, Bugdayci M, Usubutun A. Expression of p16, p53, CD24, EpCAM and calretinin in serous borderline tumors of the ovary. Turk Patoloji Derg. 2012; 28: 220-30.

[81] Hayat MA. Microscopy, immunohistochemistry, and antigen retrieval methods for light and electron microscopy. New York, Kluwer Academic Press/Plenum, 2002.

[82] Hayat MA (Ed). Handbook of immunohistochemistry and in situ hybridization of human carcinomas. Molecular Genetics, Gastrointestinal Cancer, and Ovarian Carcinoma. New York, Academic Press/Plenum, 2005.

[83] McCluggage WG. Immunohistochemical and functional biomarkers of value in female genital tract lesions. Int J Gynecol Pathol. 2006; 25: 101-20.

[84] McCluggage WG. Morphological subtypes of ovarian carcinoma: a review with emphasis on new developments and pathogenesis. Pathology. 2011; 43: 420-32.

[85] Deavers MT. Immunohistochemistry in gynecologic pathology. Arch Pathol Lab Med. 2008; 132: 175-80.

[86] Pillai G, Roberts H, Gatter K, Pezzella F. p53 expression in normal paraffin-embedded tissue using different antibodies and antigen retrieval buffer systems. Histopathology. 2003; 42: 83-7.

[87] Scott IS, Heath TM, Morris LS, Rushbrook SM, Bird K, Vowler SL, Arends MJ, Coleman N. A novel immunohistochemical method for estimating cell cycle phase distribution in ovarian serous neoplasms: implications for the histopathological assessment of paraffin-embedded specimens. Br J Cancer. 2004; 90: 1583-90.

[88] Zeren T, Inan S, Vatansever HS, Sayhan S. Significance of apoptosis related proteins on malignant transformation of ovarian tumors: A comparison between Bcl-2/Bax ratio and p53 immunoreactivity. Acta Histochem. 2014; 116: $1251-8$.

[89] Halperin R, Zehavi S, Dar P, Habler L, Hadas E, Bukovsky I, Schneider D. Clinical and molecular comparison between borderline serous ovarian tumors and advanced serous papillary ovarian carcinomas. Eur J Gynaecol Oncol. 2001; 22: 292-6.

[90] Kuwata T, Kitagawa M, Takemura T, Hirokawa K. Proliferative activity and p53 over-expression of ovarian epithelial tumors. Gen Diagn Pathol. 1995; 141: 131-9.

[91] Ozer H, Yenicesu G, Arici S, Cetin M, Tuncer E, Cetin A. Immunohistochemistry with apoptotic-antiapoptotic proteins (p53, p21, bax, bcl-2), c-kit, telomerase, and metallothionein as a diagnostic aid in benign, borderline, and malignant serous and mucinous ovarian tumors. Diagn Pathol. 2012; 7: 124.

[92] Fauvet R, Dufournet C, Poncelet C, Uzan C, Hugol D, Darai E. Expression of pro-apoptotic (p53, p21, bax, bak and fas) and anti-apoptotic (bcl-2 and bcl-x) proteins in serous versus mucinous borderline ovarian tumours. J Surg Oncol. 2005; 92: 337-43.

[93] Tiwari RK, Saha K, Mukhopadhyay D, Datta C, Chatterjee U, Ghosh TK. Evaluation of preoperative serum levels of CA 125 and expression of p53 in ovarian neoplasms: A prospective clinicopathological study in a tertiary care hospital. J Obstet Gynaecol India. 2016; 66: 107-14.

[94] Caduff RF, Svoboda-Newman SM, Ferguson AW, Johnson CM, Frank TS. Comparison of mutations of Ki-RAS and p53 immunoreactivity in borderline and malignant epithelial ovarian tumors. Am J Surg Pathol. 1999; 23: 323-8.

[95] Giordano G, Azzoni C, D’Adda T, Rocco A, Gnetti L, Froio E, Merisio C, Melpignano M. Human papilloma virus (HPV) status, p16 1NK4a, and p53 overexpression in epithelial malignant and borderline ovarian neoplasms. Pathol Res Pract. 2008; 204: 163-74.

[96] Kurman RJ, Shih I-M. Molecular pathogenesis and extraovarian origin of epithelial ovarian cancer. Shifting the paradigm. Hum Pathol. 2011; 42: 918-31.

[97] Kurman RJ, Shih I-M. The dualistic model of ovarian carcinogenesis: revisited, revised, and expanded. Am J Pathol. 2016; 186: 733-47.

[98] Aunoble B, Sanches R, Didier E, Bignon YJ. Major oncogenes and tumor suppressor genes involved in epithelial ovarian cancer (review). Int J Oncol. 2000; 16: 567-76.

[99] Balint EE, Vousden KH. Activation and activities of the p53 tumour suppressor protein. Br J Cancer. 2001; 85: 1813-23.

[100]Vergara D, Tinelli A, Martignago R, Malvasi A, Chiuri VE, Leo G. Biomolecular pathogenesis of borderline ovarian tumors: focusing target discovery through proteogenomics. Curr Cancer Drug Targ. 2010; 10: 107-16. 